Recherches en didactique des langues et des cultures

Les cahiers de l'Acedle

18-1 | 2021

En quoi les langues ont-elles un rôle à jouer dans les sociétés mondialisées au sein d'une Europe fragilisée ?

\title{
Rapports aux institutions
}

Acedle, Asdifle et TRANSIT-Lingua

\section{(2) OpenEdition}

\section{Journals}

Édition électronique

URL : https://journals.openedition.org/rdlc/8835

DOI : $10.4000 /$ rdlc. 8835

ISSN : 1958-5772

Éditeur

ACEDLE

Référence électronique

Acedle, Asdifle et TRANSIT-Lingua, "Rapports aux institutions », Recherches en didactique des langues et des cultures [En ligne], 18-1 | 2021, mis en ligne le 10 juin 2021, consulté le 04 août 2021. URL: http://journals.openedition.org/rdlc/8835; DOI : https://doi.org/10.4000/rdlc.8835

Ce document a été généré automatiquement le 4 août 2021

\section{cc) (†) $\odot$}

Recherches en didactique des langues et des cultures is licensed under a Creative Commons AttributionNonCommercial-NoDerivatives 4.0 International License 


\title{
Rapports aux institutions
}

\author{
Acedle, Asdifle et TRANSIT-Lingua
}

1 Cette capsule synthétise les moments du débat participatif concernant le rapport des chercheur.es et des professionnel.les de l'enseignement et de la diffusion des langues aux institutions, et plus particulièrement aux institutions européennes.

Ce média ne peut être affiché ici. Veuillez vous reporter à l'édition en ligne http:// journals.openedition.org/rdlc/8835

\section{Chapitrage de la capsule}

$3 \quad$ 00:26 : Daniel Coste

1:35 : Veronica Hagi

2:33 : Geneviève Zarate

3:29: Daniel Véronique

4:30 : Daniel Coste

9:05 : Aleksandra Ljalikova

9:51 : Daniel Véronique

10:48 : Michel Candelier

14:27 : Emmanuelle Huver

16:50 : Tony Liddicoat

18:35 : Jonathan Szajman

20:32 : Geneviève Zarate

21:44 : Véronique Laurens

26:22 : Alice Burrows

27:24 : Geneviève Zarate

28:07 : Daniel Coste

31:15: Fin et logos 


\section{AUTEURS}

ACEDLE

https://acedle.org/

ASDIFLE

https://asdifle.com/

TRANSIT-LINGUA

https://transitlingua.org/ 